\title{
Behavioral and steroidogenic pharmacology of phenyl ring substituted etomidate analogs in rats
}

\author{
Megan McGrath, Alissa Hofmann and Douglas E. Raines ${ }^{*}$ (i)
}

\begin{abstract}
Background: Cushing's syndrome is an endocrine disorder characterized by the overproduction of adrenocortical steroids. Steroidogenesis enzyme inhibitors are the mainstays of pharmacological treatment. Unfortunately, they produce significant side effects. Among the most potent inhibitors is the general anesthetic etomidate whose $\mathrm{GABA}_{\mathrm{A}}$ receptor-mediated sedative-hypnotic actions restrict use. In this study, we defined the sedative-hypnotic and steroidogenesis inhibiting actions of etomidate and four phenyl-ring substituted etomidate analogs (dimethoxyetomidate, isopropoxy-etomidate, naphthalene-etomidate, and naphthalene (2)-etomidate) that possess negligible $G A B A_{A}$ receptor modulatory activities.
\end{abstract}

Methods: In the first set of experiments, male Sprague-Dawley rats were assessed for loss of righting reflexes (LoRR) after receiving intravenous boluses of either etomidate $(1 \mathrm{mg} / \mathrm{kg})$ or an etomidate analog $(40 \mathrm{mg} / \mathrm{kg})$. In the second set of experiments, rats were assessed for LoRR and their abilities to produce adrenocortical and androgenic steroids after receiving 2 -h infusions $\left(0.5 \mathrm{mg} \mathrm{kg}^{-1} \mathrm{~min}^{-1}\right)$ of either etomidate or an etomidate analog.

Results: All rats that received etomidate boluses or infusions had LoRR that persisted for minutes or hours, respectively. In contrast, no rat that received an etomidate analog had LoRR. Compared to rats in the vehicle control group, rats that received etomidate analog infusions had plasma corticosterone and aldosterone concentrations that were reduced by $80-84 \%$ and $68-94 \%$, respectively. Rats that received etomidate infusions had plasma corticosterone and aldosterone concentrations that were also significantly reduced (by 92 and 96\%, respectively). Rats that received etomidate or isopropoxy-etomidate had significant reductions (90 and 57\%, respectively) in plasma testosterone concentrations whereas those that received naphthalene-etomidate had significant increases (1400\%) in plasma dehydroepiandrosterone concentrations. Neither etomidate nor any etomidate analog significantly affected plasma androstenedione and dihydrotestosterone concentrations.

Conclusions: Our studies demonstrate that the four phenyl-ring substituted etomidate analogs form a novel class of compounds that are devoid of sedative-hypnotic activities and suppress plasma concentrations of adrenocortical steroids but vary in their effects on plasma concentrations of androgenic steroids.

Keywords: Anesthetic, Corticosterone, Cushing's syndrome, Etomidate, Hypercortisolemia, Steroidogenesis

\footnotetext{
* Correspondence: draines@partners.org

Department of Anesthesia Critical Care and Pain Medicine, Massachusetts

General Hospital, 55 Fruit Street, GRB444, Boston, MA 02114, USA
}

(c) The Author(s). 2019 Open Access This article is distributed under the terms of the Creative Commons Attribution 4.0 International License (http://creativecommons.org/licenses/by/4.0/), which permits unrestricted use, distribution, and reproduction in any medium, provided you give appropriate credit to the original author(s) and the source, provide a link to the Creative Commons license, and indicate if changes were made. The Creative Commons Public Domain Dedication waiver (http://creativecommons.org/publicdomain/zero/1.0/) applies to the data made available in this article, unless otherwise stated. 


\section{Background}

Cushing's syndrome is a rare endocrine disorder that is characterized by the overproduction of adrenocortical steroids and associated with significant morbidity including insulin resistance, hypertension, immunosuppression, cardiovascular disease, neurocognitive deficits, and early mortality [1-6]. It is most commonly due to the presence of an adrenocorticotropic hormone (ACTH)secreting pituitary tumor, but may also be caused by an adrenocortical adenoma, carcinoma, or hyperplasia. Surgical intervention is typically the treatment of choice; however, recurrence after surgery is common, necessitating long-term pharmacological management to suppress cortisol production [7-12]. Pharmacological management may also be administered preoperatively to reduce surgical risk, to treat metastatic disease, or combined with radiotherapy as an alternative or in addition to surgery $[13,14]$.

Although several classes of drugs can be utilized in the treatment of Cushing's syndrome, steroidogenesis enzyme inhibitors are the mainstays of pharmacological management [15]. Steroidogenesis inhibitors suppress cortisol production by inhibiting enzymes required for the biosynthesis of adrenocortical steroids (Fig. 1). These enzymes fall into one of two structurally related superfamilies, cytochrome P450s and hydroxysteroid dehydrogenases. The most commonly employed steroidogenesis enzyme inhibitors are ketoconazole and metyrapone, although aminoglutethimide, mitotane, and fluconazole are also sometimes used [15]. Unfortunately, all of these drugs have significant adverse side effects that limit dosing, clinical effectiveness, and patient tolerability, and none have been approved by the United States Food and Drug Administration for the treatment of Cushing's syndrome. Consequently, there are ongoing efforts to develop new drugs with improved pharmacological profiles [16].

Etomidate is a general anesthetic induction agent that exerts its sedative-hypnotic actions via its positive modulatory actions on the $\mathrm{GABA}_{\mathrm{A}}$ receptor [17]. It is also used "off-label" to treat Cushing's syndrome because it potently inhibits the function of the adrenocortical CYP enzyme $11 \beta$-hydroxylase and potently suppresses the synthesis of cortisol [18-20]. Within the context of its use as a steroidogenesis enzyme inhibitor, the $\mathrm{GABA}_{\mathrm{A}}$ receptor modulatory activity and resultant sedative-hypnotic actions of etomidate are undesirable side effects that have led to recommendations that etomidate administration be restricted to highly monitored hospital environments such as an intensive care unit [15, 20-22]. These side effects are most likely to be encountered when employing a "block and replace" strategy where the goal is to completely inhibit cortisol biosynthesis (and then to administer replacement corticosteroids) because relatively high etomidate doses are required. As part of a strategy to overcome this limitation we developed (R)-ethyl 1-(1-(3,5-dimethoxyphenyl)ethyl)-1Himidazole-5-carboxylate (dimethoxy-etomidate), a phenyl ring substituted etomidate analog that retains the potent $11 \beta$-hydroxylase inhibitory activity of etomidate but is essentially devoid of the drug's $\mathrm{GABA}_{\mathrm{A}}$ receptor modulatory and sedative-hypnotic actions [23]. In the current manuscript, we describe studies to further define the pharmacology of this compound along with three additional phenyl ring substituted etomidate analogs that are similarly lacking in significant $\mathrm{GABA}_{\mathrm{A}}$ receptor modulatory activity (Fig. 2) [24]. We also characterized the pharmacology of etomidate to provide context. Our studies show that these phenyl ring substituted etomidate analogs form a novel class of compounds that retain the ability of etomidate to suppress adrenocortical steroid biosynthesis but do not have sedative-hypnotic activity. However, despite their similar inhibitory actions on adrenocortical steroid biosynthesis, these etomidate analogs variably affect the biosynthesis of individual androgenic steroids.

\section{Methods}

\section{Sources of drugs and chemicals}

$\mathrm{ACTH}$, human chorionic gonadotropin hormone (hCG), and Glycine- $\mathrm{HCl}$ were purchased from Sigma-Aldrich Chemical Company (St. Louis, MO, USA). Isoflurane was purchased from Patterson Veterinary (Saint Paul, MN, USA). Heparin and saline were purchased from Hospira (Lake Forest, IL, USA). EDTA-containing vacutainer tubes were purchased from Becton Dickinson (Franklin Lakes, NJ, USA). Etomidate was purchased from Bachem (Torrance, CA, USA). Enzyme-linked immunosorbent assay kits for corticosterone were purchased from IDS (Gaithersburg, MD, USA), whereas those for aldosterone, dehydroepiandrosterone (DHEA), and testosterone were purchased from Enzo Life Sciences (Farmingdale, NY, USA), and those for androstenedione and dihydrotestosterone were purchased from MyBioSource (Cambridge, MA, USA). Dimethoxyetomidate, $(R)$-ethyl 1-(1-(3-isopropoxyphenyl)ethyl)-1Himidazole-5-carboxylate (isopropoxy-etomidate), $(R)$-ethyl 1-(1-(naphthalen-2-yl)ethyl)- $1 H$-imidazole-5-carboxylate (naphthalene-etomidate), and $(R)$-ethyl 1-(1-(naphthalen1-yl)ethyl)- $1 H$-imidazole-5-carboxylate (naphthalene (2)etomidate) were custom synthesized by Aberjona Laboratories (Beverly, MA, USA) and their structures confirmed by nuclear magnetic resonance spectroscopy.

\section{Animals}

All studies were conducted with the approval of and in accordance with rules and regulations of the Institutional Animal Care and Use Committee at the Massachusetts 


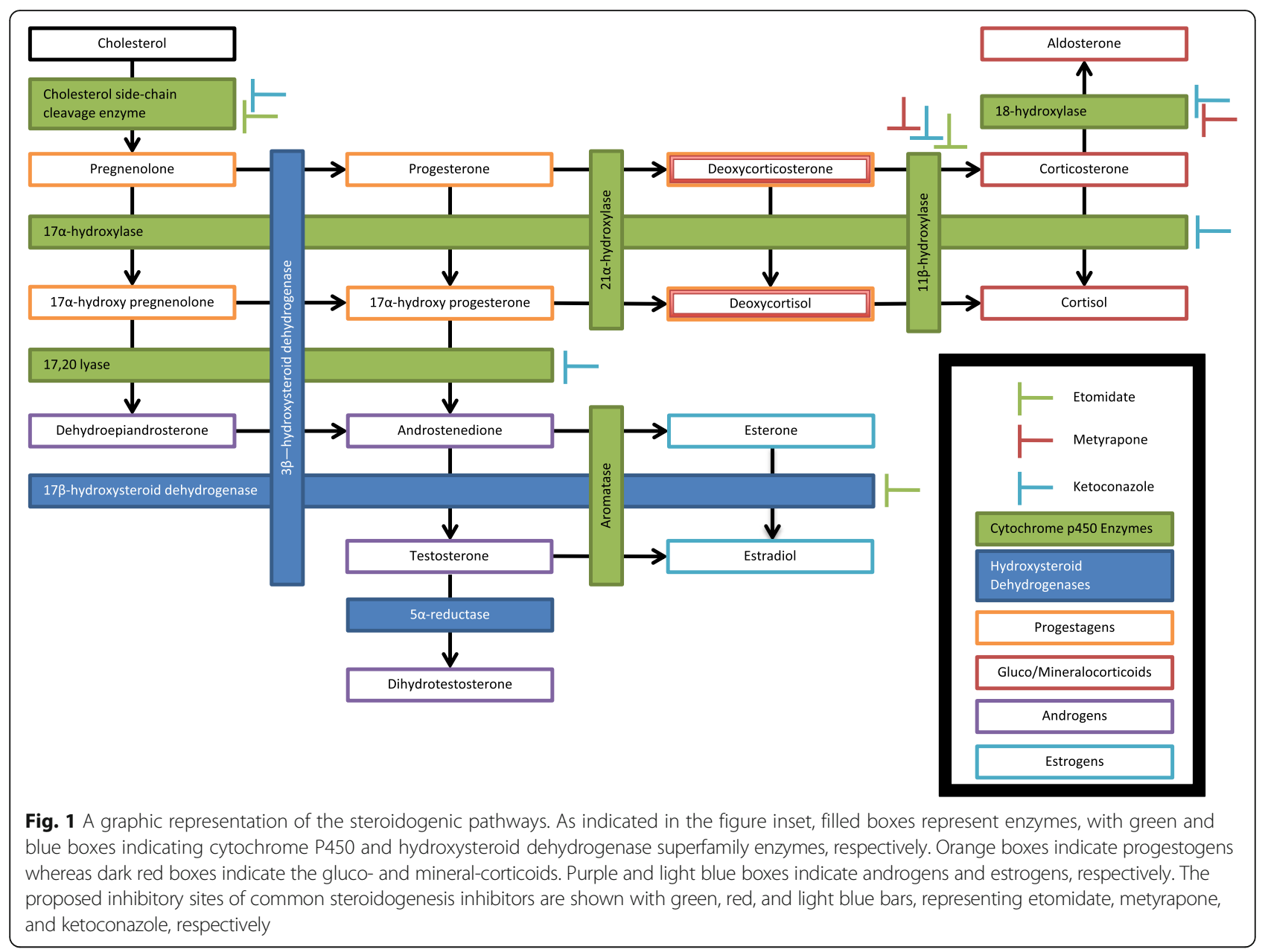

General Hospital, Boston, Massachusetts (Protocol \# 2013 N000130) and the principles outlined in the Guide for the Care and Use of Laboratory Animals from the National Institutes of Health. Adult male Sprague-Dawley rats $(300-500 \mathrm{~g})$ were purchased from Charles River
Laboratories (Wilmington, MA, USA) and housed with a 12-12 light-dark cycle with light switched on at 7 AM. Rats were caged in our animal care facility, which is maintained at $22.5^{\circ} \mathrm{C}$, and allowed free access to food and drinking water until the day of study. Rats were housed<smiles>CCOC(=O)c1cncn1C(C)c1ccccc1</smiles>

Etomidate

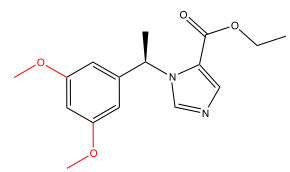

DimethoxyEtomidate<smiles>CCOC(=O)c1cccn1C(C)c1cccc(OC(C)C)c1</smiles>

IsopropoxyEtomidate
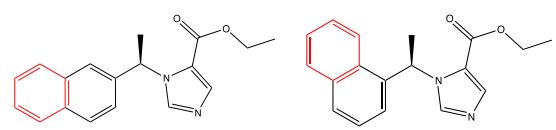

Naphthalene-
Naphthalene(2)-
Etomidate

Fig. 2 Chemical structures of etomidate and the four etomidate analogs examined. Benzene ring modifications for each analog are highlighted in red 
socially (i.e. with other rats) whenever possible with access to enrichment materials (wooden block and plastic tube). Each rat was weighed on the day of study. All studies were performed in our laboratory at the Massachusetts General Hospital and carried out at room temperature. During infusions, animal core temperature was monitored and maintained at a target temperature of $36-37^{\circ} \mathrm{C}$ using a heat lamp. At the end of study, all animals were euthanized by our veterinary staff in the animal care facility by carbon dioxide asphyxiation or in our laboratory under propofol anesthesia using intravenous $\mathrm{KCl}$ as recommended under American Veterinary Medical Association guidelines.

\section{Etomidate and etomidate analog formulation, dosing and administration}

For experiment 1, our goal was to test all etomidate analogs for sedative-hypnotic activity at the highest attainable intravenous bolus dose that was reliably non-lethal. That dose was determined in pilot studies to be $40 \mathrm{mg}$ $\mathrm{kg}^{-1}$. An etomidate intravenous bolus dose of $1 \mathrm{mg} \mathrm{kg}^{-1}$ was chosen for context with the expectation that it would produce loss of righting reflexes in all rats [25]. On the day of study, rats were blocked randomized into 6 rats per treatment group (i.e. etomidate group, dimethoxy-etomidate group, naphthalene-etomidate group, naphthalene (2)-etomidate group). To allow intravenous dosing, a 24-gauage catheter was placed in a tail vein under brief isoflurane $(2-3 \%)$ anesthesia. This method of anesthesia was chosen to allow rapid reversibility. Catheter patency was maintained with a heparin lock flush. Animals were then allowed to recover for at least 2 hours prior to study. Etomidate and etomidate analogs were formulated for these bolus studies using Captisol (Ligand, San Diego, CA) at a 1:1 M ratio in distilled water at concentrations of $2 \mathrm{mg} / \mathrm{ml}$ and 50 $\mathrm{mg} / \mathrm{ml}$, respectively.

For experiment 2, our primary goal was to assess the impact of 2-h etomidate and etomidate analog infusions on steroidogenesis. Our secondary goal was to determine whether such infusions produce sedation/hypnosis. For these studies, we used the highest attainable dose $(0.5$ $\mathrm{mg} \mathrm{kg}^{-1} \mathrm{~min}^{-1}$ ) given the limitations in etomidate and analog aqueous solubility and infusion volume constraints in rats. On the day of study, rats were block randomized into 6 rats per treatment group (i.e. vehicle control group, etomidate group, dimethoxy-etomidate group, naphthalene-etomidate group, naphthalene (2)etomidate group). Two 24-gauge intravenous catheters were placed in each rat (one in each lateral tail vein) under brief isoflurane (2-3\%) anesthesia to allow the reliable intravenous administration of drugs and test compounds and to draw blood. Catheter patency was maintained with a heparin lock flush. Animals were then allowed to recover for at least 2 hours prior to study. To avoid potential interference with our steroid assays by Captisol [26, 27], etomidate and etomidate analogs were formulated for these infusion studies on the study day in $10 \mathrm{mM}$ glycine- $\mathrm{HCl}$ buffer ( $\mathrm{pH} 2-2.2)$ at a concentration of $3 \mathrm{mg} / \mathrm{ml}$.

\section{Loss of righting reflex by etomidate and etomidate analogs}

Immediately after receiving an etomidate or etomidate analog bolus (Experiment 1) or at the end of a 2-h etomidate or etomidate analog infusion (Experiment 2), each rat was assessed for sedation/hypnosis using a loss of righting reflex assay [28]. In this assay, a rat is determined to have lost its righting reflexes if (after being turned supine) it fails to turn itself back onto all four paws within $5 \mathrm{~s}$. Each rat that has loss of righting reflexes is then monitored and the duration of loss of righting reflexes defined as the time when etomidate or etomidate analog administration was complete until the animal returned onto all four paws.

\section{Steroidogenesis inhibition by etomidate and etomidate analogs}

In Experiment 2, the in vivo steroidogenic actions of etomidate and etomidate analogs were assessed in male rats (six per group) using a hormone stimulation test (Fig. 3). For the 2 days immediately prior to study, rats were restrained in a broome style rodent restrainer from $10 \mathrm{AM}$ until 4PM to accommodate them to this environment and reduce stress-induced fluctuations in steroid biosynthesis. On the study day, each rat was placed in a restrainer at $10 \mathrm{AM}$ and intravenous catheters were placed as described above. At $1 \mathrm{PM}$, a 2-h infusion of $0.5 \mathrm{mg} /$ $\mathrm{kg} / \mathrm{min}$ etomidate, etomidate analog, or an equivalent volume of $10 \mathrm{mM}$ Glycine- $\mathrm{HCl}, \mathrm{pH} 2.2$ vehicle was started. At the timepoints indicated in Fig. 3, adrenocortical and androgenic steroid biosynthesis was stimulated in rats by administering intravenous ACTH $(25 \mu \mathrm{g} / \mathrm{kg})$ and hCG $(10 \mathrm{U} / \mathrm{kg})$, respectively. At the end of the infusion, a blood sample was drawn and rats were assessed for loss of righting reflexes as described in the following section. Stimulated plasma steroid concentrations were determined using enzyme-linked immunosorbent assays and a 96-well plate reader (Molecular Devices, Sunnyvale, $\mathrm{CA}$ ).

\section{Statistical analysis}

All individual data points are expressed as the mean \pm the S.E.M. of six independent measurements. Group size was chosen based on previous experience [23]. Statistical analyses to assess differences in plasma steroid concentrations between etomidate or etomidate analog groups versus the vehicle control groups were carried out with 

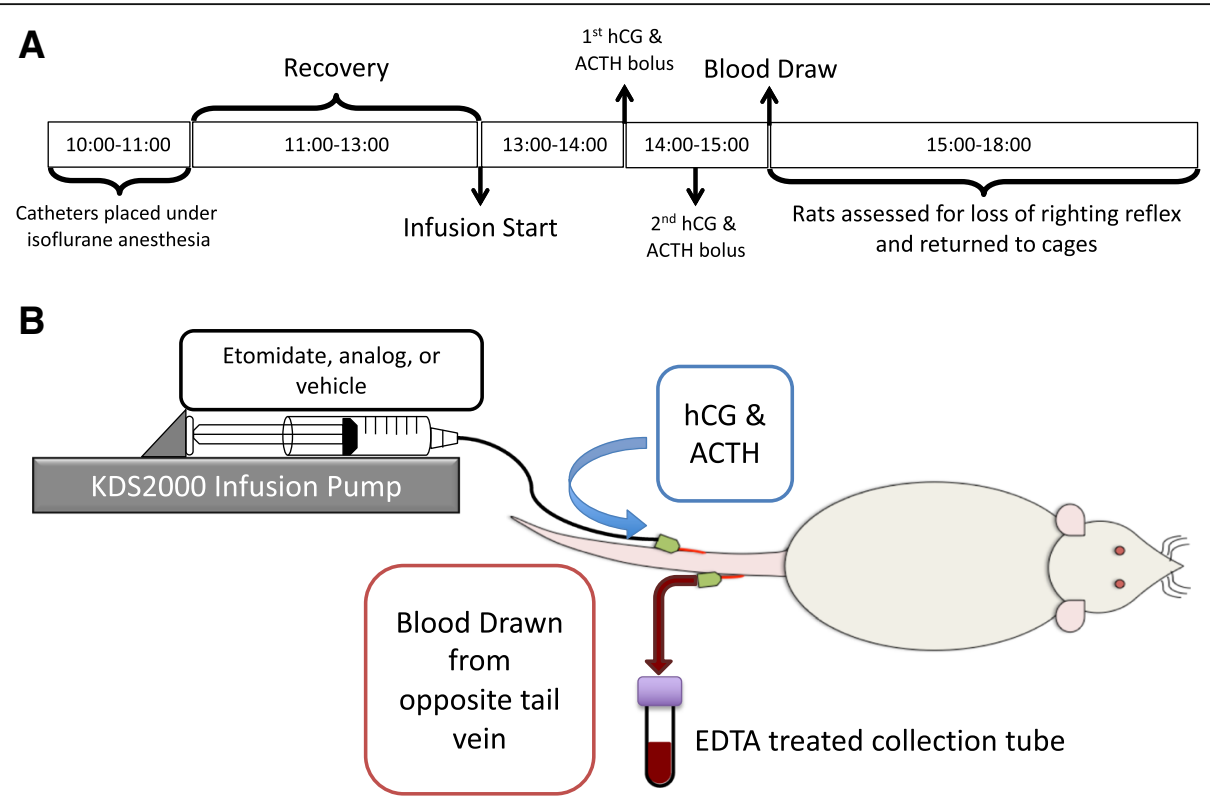

Fig. 3 Graphic representation of the experimental protocol. a Boxes show the protocol on experimental days. $\mathbf{b}$ A graphic representation of the experimental set-up

a Mann-Whitney U test using Prism 5 for Mac OS X. A Bonferroni correction was used to account for multiple (i.e. five) comparisons. Thus, statistical significance was assumed for a $p<0.01$.

\section{Results}

\section{Experiment 1}

\section{Sedative-hypnotic actions of etomidate and etomidate} analogs following bolus administration

All rats that received an etomidate bolus $(1 \mathrm{mg} / \mathrm{kg} ; n=6$ rats) exhibited loss of righting reflexes. This loss of righting reflexes lasted for $3.4 \pm 0.3 \mathrm{~min}$. In contrast, none of the rats that received an etomidate analog bolus ( $40 \mathrm{mg} / \mathrm{kg} ; \mathrm{n}=6$ rats $\times 4$ analogs) exhibited loss of righting reflexes.

\section{Experiment 2}

\section{Sedative-hypnotic actions of etomidate and etomidate} analogs following $2-\boldsymbol{h}$ infusion

All 6 rats that received etomidate exhibited loss of righting reflexes when assessed at the end of the 2-h etomidate infusion. Such loss of righting reflexes persisted for $152 \pm 3 \mathrm{~min}$ (range: 146-157 min). In contrast, none of the 24 rats that received a $2-\mathrm{h}$ infusion of any of the four etomidate analogs (or the 6 that received vehicle alone) exhibited loss of righting reflexes.

\section{Impact of etomidate and etomidate analogs on plasma adrenocortical steroid concentrations}

Consistent with our previous studies [23, 29, 30], both etomidate and dimethoxy-etomidate significantly reduced
ACTH-stimulated plasma corticosterone concentrations in rats by 92 and $84 \%$, respectively, as compared to those concentrations measured in vehicle control group rats. We similarly found that the three new phenyl ring substituted etomidate analogs isopropoxy-etomidate, naphthalene-etomidate, and naphthalene (2)-etomidate significantly reduced such concentrations by 86,80 , and $82 \%$, respectively (Fig. 4a). Etomidate and all four of the etomidate analogs also significantly reduced ACTH-stimulated plasma aldosterone concentrations in rats by $96 \%$ (etomidate), $94 \%$ (dimethoxy-etomidate), 76\% (isopropoxy-etomidate), 68\% (naphthalene-etomidate) and 71\% (naphthalene (2)-etomidate) as compared to those concentrations measured in vehicle control group rats (Fig. 4b).

\section{Impact of etomidate and etomidate analogs on plasma androgenic steroid concentrations}

In contrast to their similar inhibitory actions on stimulated plasma concentrations of the two adrenocortical steroids (corticosterone and aldosterone), etomidate and the four etomidate analogs varied in their impact on stimulated plasma concentrations of the androgenic steroids testosterone (Fig. 5a) and dehydroepiandrosterone (Fig. 5b) and had no significant effect on plasma concentrations of androstenedione (Fig. 5c) and dihydrotestosterone (Fig. 5d). Specifically, etomidate significantly reduced hCG-stimulated plasma testosterone concentrations in rats by an order of magnitude from a vehicle control value of $31,000 \pm 1800 \mathrm{pg} / \mathrm{mL}$ to $3000 \pm 1100 \mathrm{pg} /$ $\mathrm{mL}$ whereas dimethoxy-etomidate had no effect at all $(31,000 \pm 3100 \mathrm{pg} / \mathrm{mL})$. The other three etomidate analogs 


\section{A \\ Corticosterone \\ B Aldosterone}
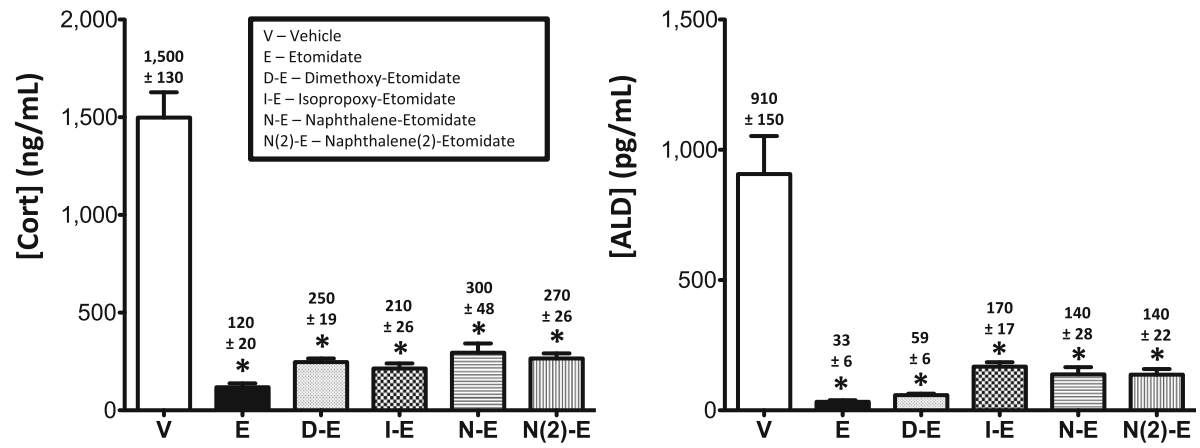

Fig. 4 Adrenocorticotropic hormone-stimulated plasma concentrations of (a) corticosterone and (b) aldosterone following administration of vehicle or $0.5 \mathrm{mg} / \mathrm{kg} / \mathrm{min}$ IV etomidate, dimethoxy-etomidate, isopropoxy-etomidate, naphthalene-etomidate, or naphthalene (2)-etomidate to rats. Abbreviations for each test compound are defined in panel A. Each bar represents the mean \pm SEM from 6 rat experiments. ${ }^{*} p<0.01$

modestly reduced plasma testosterone concentrations in hCG-stimulated rats to values of $13,400 \pm 2300$ (isopropoxy-etomidate), $18,200 \pm 5500$ (naphthalene-etomidate), and 25,900 \pm 3800 (naphthalene (2)-etomidate). However, only the reduction by isopropoxy-etomidate reached statistical significance (Fig. 5a).
Both naphthalene-etomidate and naphthalene (2)-etomidate increased hCG-stimulated plasma DHEA concentrations in rats from a vehicle control value of $750 \pm$ $330 \mathrm{pg} / \mathrm{mL}$ to values of $11,600 \pm 2600 \mathrm{pg} / \mathrm{mL}$ and $2800 \pm$ $590 \mathrm{pg} / \mathrm{mL}$, respectively. In the case of naphthalene-etomidate, this increase (1400\%) reached statistical

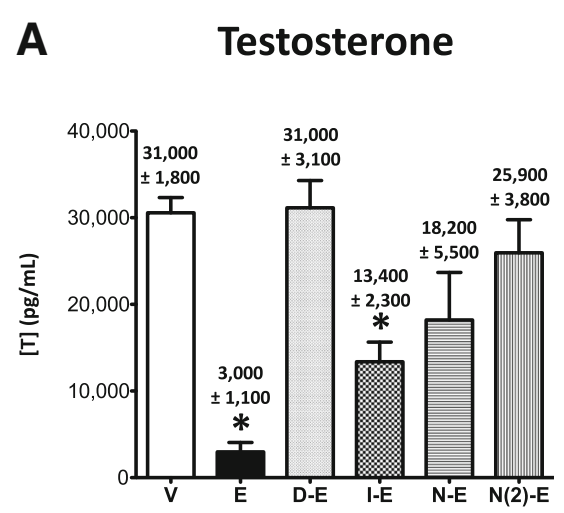

C

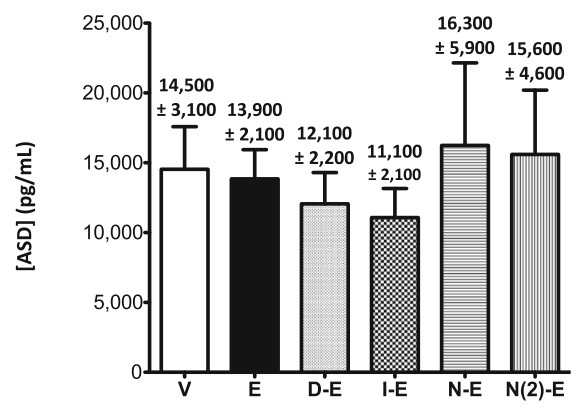

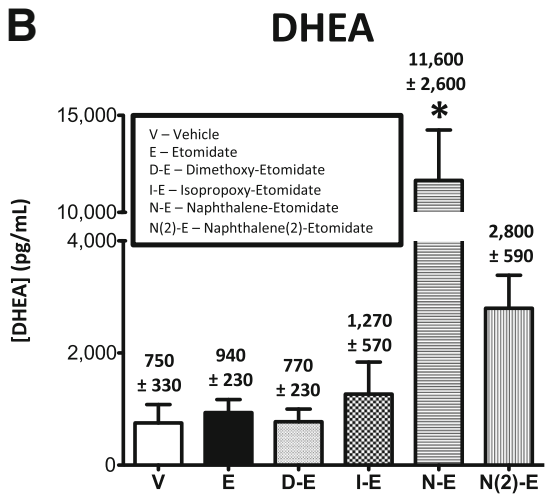

D Dihydrotestosterone

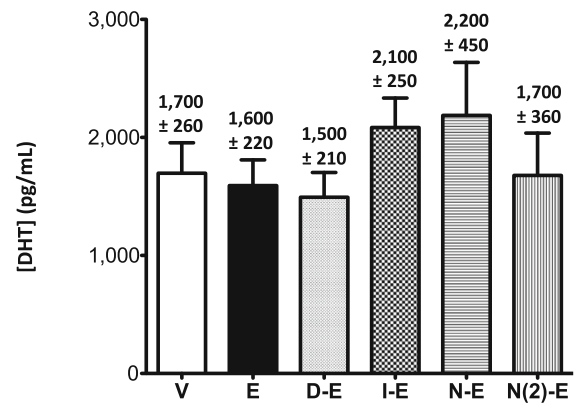

Fig. 5 Human Chorionic Gonadotropin-stimulated plasma concentrations of (a) testosterone, (b) dehydroepiandrosterone (DHEA), (c) androstenedione, and (d) dihydrotestosterone following administration of vehicle or $0.5 \mathrm{mg} / \mathrm{kg} / \mathrm{min}$ IV etomidate, dimethoxy-etomidate, isopropoxy-etomidate, naphthaleneetomidate, or naphthalene (2)-etomidate to rats. Abbreviations for each test compound are defined in panel B. Each bar represents the mean \pm SEM from 6 rat experiments. ${ }^{*} p<0.01$ 
significance. hCG-stimulated plasma DHEA concentrations in rats that received etomidate $(940 \pm 230 \mathrm{ng} / \mathrm{mL})$, dimethoxy-etomidate $(770 \pm 230 \mathrm{ng} / \mathrm{mL})$, and isopropoxyetomidate $(1270 \pm 570 \mathrm{ng} / \mathrm{mL})$ were not significantly different from those in the vehicle control group (Fig. 5b).

The hCG-stimulated plasma concentrations of androstenedione and dihydrotestosterone in control rats that had received vehicle alone were $14,500 \pm 3100 \mathrm{pg} / \mathrm{mL}$ and $1700 \pm 260 \mathrm{pg} / \mathrm{mL}$, respectively. Neither etomidate nor any of the etomidate analogs studied had any significant effect on hCG-stimulated plasma concentrations of these two androgens (Figs. 5c \& d).

\section{Discussion}

In the current manuscript, we report the results of animal studies aimed at further defining the pharmacology of dimethoxy-etomidate - a potential lead compound for the development of new drugs to treat Cushing's syndrome - and three new etomidate analogs that also contain bulky phenyl-ring substituent groups and are essentially devoid of $\mathrm{GABA}_{\mathrm{A}}$ receptor modulatory activity. In addition, we describe the results of studies using the sedative-hypnotic etomidate to provide context. We show that the four phenyl-ring substituted etomidate analogs form a novel class of etomidate analogs that (1) unlike etomidate, are essentially devoid of sedative-hypnotic activities; (2) similar to etomidate, suppress plasma concentrations of adrenocortical steroids; and (3) vary in their effects on plasma concentrations of androgenic steroids.

Steroid biosynthesis is primarily mediated by enzymes belonging to the cytochrome $\mathrm{p} 450$ and hydroxysteroid dehydrogenase superfamilies. The structures of the enzymes that comprise each of these superfamilies are highly homologous, explaining the low selectivities that most exogenous ligands (e.g. steroidogenesis inhibitors) possess for superfamily members [31]. For example, ketoconazole inhibits $17 \alpha$-hydroxylase, cholesterol side chain cleavage enzyme, $11 \beta$-hydroxylase, 18 -hydroxylase, and 17,20-lyase [15]. At clinical doses, metyropone inhibits both $11 \beta$-hydroxylase and the closely related enzyme 18-hydroxylase [15]. For each steroidogenesis inhibitor, the specific pattern of enzyme inhibition determines whether it will cause the plasma concentration of a particular steroid to rise or fall. Because ketoconazole inhibits enzymatic steps that are relatively proximal in the steroidogenesis pathway and thus required for the biosynthesis of both adrenocortical and androgenic steroids, it reduces the plasma concentrations of steroids from both classes (e.g. cortisol and testosterone, respectively). This leads to side effects in male patients that are attributable to low androgen levels such as decreased libido and gynecomastia [13, 32, 33]. In contrast, the two enzymes inhibited by metyropone are near the end of the steroidogenesis pathway and required only for adrenocortical steroid biosynthesis. Inhibition of these two enzymes selectively reduces adrenocortical steroid production and causes adrenocortical steroid precursors to accumulate. These precursors may then be shunted into the androgen (and mineralcorticoid) steroid biosynthetic pathway, increasing androgenic steroid levels and causing such side effects as acne, hirsutism, virilism, hypertension, and infertility [13, 34-37].

As expected, we found that all rats that received a 1 $\mathrm{mg} / \mathrm{kg}$ etomidate bolus or 2-h etomidate infusion exhibited loss of righting reflexes, an animal correlate for sedation/hypnosis. In contrast, none of the rats that received a 40-fold higher bolus dose of an etomidate analog (i.e. $40 \mathrm{mg} / \mathrm{kg}$ ) or a 2-h etomidate analog infusion lost their righting reflexes. Such a lack of sedative-hypnotic activity among the etomidate analogs is consistent with previous electrophysiological work showing that these analogs are essentially devoid of the $\mathrm{GABA}_{\mathrm{A}}$ receptor positive modulatory actions thought to mediate the sedative-hypnotic effects of etomidate [24, 38, 39].

Consistent with previous studies, we also found that etomidate reduces plasma concentrations of corticosterone and aldosterone $[23,29,30]$. This action has been attributed to inhibition of $11 \beta$-hydroxylase and 18 hydroxylase, mechanisms that it shares with metyrapone [15]. Molecular docking studies utilizing these two highly homologous enzymes indicate that high affinity binding of etomidate and metyrapone is mediated by a coordination bond that forms between the aromatic nitrogen found in the imidazole ring of these drugs and the heme iron located at the active sites of the two enzymes [31]. In the case of etomidate, the critical nature of this interaction has been confirmed by studies using a pyrrole etomidate analog (carboetomidate) that is unable to form such a bond; carboetomidate possesses an in vitro enzymatic binding affinity and an in vivo adrenocortical inhibitory potency that are three orders of magnitude lower than those of etomidate [40, 41]. Other important interactions identified by docking studies include a hydrogen bonding interaction between the etomidate ester moiety and Thr318 in the active site and a ring stacking interaction between the etomidate phenyl ring and Phe130 in the active site [31]. These are interactions that are expected to be maintained with all four phenyl ring substituted etomidate analogs. However, the active site cavity volumes of these two enzymes are estimated to be $360 \AA^{3}$ (11ß-hydroxylase) and $334 \AA^{3}$ (18hydroxylase), which are only modestly larger than the molecular volume of etomidate $\left(269.7 \AA^{3}\right)$ [31]. The addition of the various bulky substituents groups to etomidate (to form our four etomidate analogs) increases molecular volume by between $39.9 \AA^{3}$ and $52.7 \AA^{3}$, potentially introducing steric hindrance and reducing the 
binding affinity to these enzymes [24]. Such a reduction in affinity could explain - at least in part - why the four phenyl ring substituent-containing analogs tended to produce smaller reductions in plasma corticosterone and aldosterone concentrations than etomidate.

Although etomidate and all four etomidate analogs significantly reduced plasma concentrations of both adrenocortical steroids, only two compounds (etomidate and isopropoxy-etomidate) significantly reduced those of any androgenic steroid. This reduction was limited to testosterone, whose plasma concentrations were reduced by $90 \%$ (etomidate) and $57 \%$ (isopropoxy-etomidate). In contrast, naphthalene-etomidate actually increased plasma concentrations of the androgenic steroid DHEA by more than an order of magnitude without significantly affecting those of the other androgenic steroids. Unfortunately, the mechanisms responsible for these actions cannot be unambiguously determined from our data. However, previous in vitro studies indicate that etomidate can inhibit $17 \beta$-hydroxysteroid dehydrogenase leading to suppression of testosterone synthesis.

\section{Conclusions}

In conclusion, we have defined a novel class of steroidogenic enzyme inhibitors consisting of etomidate analogs that contain bulky phenyl ring substituent groups. Compounds in this class are devoid of sedative-hypnotic activity and inhibit stimulated plasma adrenocortical steroid concentrations, but differ in their effects on stimulated plasma androgenic steroid concentrations. They provide a proof-of-concept for the development of nonsedating etomidate analogs to treat Cushing's syndrome as well as other pathologies whose clinical courses may be improved by altering steroid biosynthesis.

\section{Abbreviations \\ ACTH: Adrenocorticotropic hormone; DHEA: Dehydroepiandrosterone; Dimethyoxy-etomidate: (R)-ethyl 1-(1-(3,5-dimethoxyphenyl)ethyl)-1 H- imidazole-5-carboxylate; $G_{A B A}$ receptor: Gamma aminobutyric acid type A receptor; hCG: Human chorionic gonadotropin hormone; Isopropoxy- etomidate: $(R)$-ethyl 1-(1-(3-isopropoxyphenyl)ethyl)-1H-imidazole-5-carboxylate; Naphthalene (2)-etomidate: $(R)$-ethyl 1-(1-(naphthalen-1-yl)ethyl)-1H-imidazole-5- carboxylate; Naphthalene-etomidate: (R)-ethyl 1-(1-(naphthalen-2-yl)ethyl)-1H- imidazole-5-carboxylate}

\section{Acknowledgements}

Not applicable.

\begin{abstract}
Authors' contributions
MM participated in the study design, conducted experiments, performed data analyses, and assisted in writing the manuscript. AH conducted experiments. DER conceived the idea for the study, helped in study design, and wrote the manuscript. All authors read and approved the final manuscript.
\end{abstract}

\section{Funding}

This work was supported by the National Institutes of Health, Bethesda, MD [GM087316 and GM122806] and the Department of Anesthesia, Critical Care, and Pain Medicine, Massachusetts General Hospital, Boston, Massachusetts.
These entities had no role in the design of the studies or the collection, analysis, or interpretation of data or in writing the manuscript.

\section{Availability of data and materials}

The datasets used and/or analyzed during the current study are available from the corresponding author on reasonable request.

\section{Ethics approval}

All studies were conducted with the approval of and in accordance with rules and regulations of the Institutional Animal Care and Use Committee at the Massachusetts General Hospital, Boston, Massachusetts.

\section{Consent for publication}

Not applicable.

\section{Competing interests}

The authors declare that they have no competing interests.

Received: 19 June 2019 Accepted: 29 July 2019

Published online: 05 August 2019

\section{References}

1. Lacroix A, Feelders RA, Stratakis CA, Nieman LK. Cushing's syndrome. Lancet. 2015;386(9996):913-27. https://doi.org/10.1016/S0140-6736(14)61375-1.

2. Tritos NA, Biller BM. Cushing's disease. Handb Clin Neurol. 2014;124:221-34. https://doi.org/10.1016/B978-0-444-59602-4.00015-0.

3. Pivonello R, Isidori AM, De Martino MC, Newell-Price J, Biller BM, Colao A. Complications of Cushing's syndrome: state of the art. Lancet Diabetes Endocrinol. 2016;4(7):611-29. https://doi.org/10.1016/S2213-8587(16)00086-3.

4. Pivonello R, De Martino MC, De Leo M, Simeoli C, Colao A. Cushing's disease: the burden of illness. Endocrine. 2017;56(1):10-8. https://doi.org/1 0.1007/s12020-016-0984-8.

5. Mancini T, Kola B, Mantero F, Boscaro M, Arnaldi G. High cardiovascular risk in patients with Cushing's syndrome according to $1999 \mathrm{WHO} / \mathrm{ISH}$ guidelines. Clin Endocrinol. 2004;61(6):768-77. https://doi.org/10.1111/ j.1365-2265.2004.02168.x.

6. Dekkers OM, Horvath-Puho E, Jorgensen JO, Cannegieter SC, Ehrenstein V, Vandenbroucke JP, Pereira AM, Sorensen HT. Multisystem morbidity and mortality in Cushing's syndrome: a cohort study. J Clin Endocrinol Metab. 2013;98(6):2277-84. https://doi.org/10.1210/jc.2012-3582.

7. Atkinson AB, Kennedy A, Wiggam MI, McCance DR, Sheridan B. Long-term remission rates after pituitary surgery for Cushing's disease: the need for long-term surveillance. Clin Endocrinol. 2005;63(5):549-59. https://doi.org/1 0.1111/j.1365-2265.2005.02380.x.

8. Fleseriu M, Loriaux DL, Ludlam WH. Second-line treatment for Cushing's disease when initial pituitary surgery is unsuccessful. Curr Opin Endocrinol Diabetes Obes. 2007;14(4):323-8. https://doi.org/10.1097/MED.0b013e32824 8b498.

9. Patil CG, Prevedello DM, Lad SP, Vance ML, Thorner MO, Katznelson L, Laws ER Jr. Late recurrences of Cushing's disease after initial successful transsphenoidal surgery. J Clin Endocrinol Metab. 2008;93(2):358-62. https://doi.org/10.1210/jc.2 007-2013.

10. Alexandraki Kl, Kaltsas GA, Isidori AM, Storr HL, Afshar F, Sabin I, Akker SA, Chew SL, Drake WM, Monson JP, et al. Long-term remission and recurrence rates in Cushing's disease: predictive factors in a single-Centre study. Eur J Endocrinol. 2013;168(4):639-48. https://doi.org/10.1530/EJE-12-0921.

11. Dimopoulou C, Schopohl J, Rachinger W, Buchfelder M, Honegger J, Reincke M, Stalla GK. Long-term remission and recurrence rates after first and second transsphenoidal surgery for Cushing's disease: care reality in the Munich metropolitan region. Eur J Endocrinol. 2014;170(2): 283-92. https://doi.org/10.1530/EJE-13-0634.

12. Pivonello R, De Leo M, Cozzolino A, Colao A. The treatment of Cushing's disease. Endocr Rev. 2015;36(4):385-486. https://doi.org/10.1210/er.2013-1048.

13. Cuevas-Ramos D, Fleseriu M. Treatment of Cushing's disease: a mechanistic update. J Endocrinol. 2014;223(2):R19-39. https://doi.org/10.1530/JOE-14-0300.

14. Fleseriu M, Castinetti $F$. Updates on the role of adrenal steroidogenesis inhibitors in Cushing's syndrome: a focus on novel therapies. Pituitary. 2016; 19(6):643-53. https://doi.org/10.1007/s11102-016-0742-1.

15. Daniel E, Newell-Price JD. Therapy of endocrine disease: steroidogenesis enzyme inhibitors in Cushing's syndrome. Eur J Endocrinol. 2015;172(6): R263-80. https://doi.org/10.1530/EJE-14-1014. 
16. Stormann S, Schopohl J. New and emerging drug therapies for Cushing's disease. Expert Opin Pharmacother. 2018;19(11):1187-200. https://doi.org/ 0.1080/14656566.2018.1504021.

17. Forman SA. Clinical and molecular pharmacology of etomidate. Anesthesiology. 2011;114(3):695-707. https://doi.org/10.1097/ALN.0b013e3181ff72b5.

18. Schulte HM, Benker G, Reinwein D, Sippell WG, Allolio B. Infusion of low dose etomidate: correction of hypercortisolemia in patients with Cushing's syndrome and dose-response relationship in normal subjects. J Clin Endocrinol Metab. 1990;70(5):1426-30. https://doi.org/10.1210/jcem70-5-1426.

19. Greening JE, Brain CE, Perry LA, Mushtaq I, Sales Marques J, Grossman AB, Savage MO. Efficient short-term control of hypercortisolaemia by low-dose etomidate in severe paediatric Cushing's disease. Horm Res. 2005;64(3):1403. https://doi.org/10.1159/000088587.

20. Preda VA, Sen J, Karavitaki N, Grossman AB. Etomidate in the management of hypercortisolaemia in Cushing's syndrome: a review. Eur J Endocrinol. 2012;167(2):137-43. https://doi.org/10.1530/EJE-12-0274.

21. Nieman LK, Biller BM, Findling JW, Murad MH, Newell-Price J, Savage MO, Tabarin A, Endocrine S. Treatment of Cushing's syndrome: an Endocrine Society clinical practice guideline. J Clin Endocrinol Metab. 2015;100(8): 2807-31. https://doi.org/10.1210/jc.2015-1818.

22. Tritos NA, Biller BM. Medical management of Cushing's disease. J NeuroOncol. 2014;117(3):407-14. https://doi.org/10.1007/s11060-013-1269-1.

23. McGrath M, Ma C, Raines DE. Dimethoxy-etomidate: a nonhypnotic etomidate analog that potently inhibits steroidogenesis. J Pharmacol Exp Ther. 2018; 364(2):229-37. https://doi.org/10.1124/jpet.117.245332.

24. McGrath M, Yu Z, Jayakar SS, Ma C, Tolia M, Zhou X, Miller KW, Cohen JB, Raines DE. Etomidate and etomidate analog binding and positive modulation of gamma-aminobutyric acid type a receptors: evidence for a state-dependent cutoff effect. Anesthesiology. 2018;129(5):959-69. https://doi.org/10.1097/ALN. 0000000000002356

25. Pejo E, Santer P, Jeffrey S, Gallin H, Husain SS, Raines DE. Analogues of etomidate: modifications around etomidate's chiral carbon and the impact on in vitro and in vivo pharmacology. Anesthesiology. 2014;121(2):290-301. https://doi.org/10.1097/ALN.0000000000000268.

26. Frijlink HW, Eissens AC, Hefting NR, Poelstra K, Lerk CF, Meijer DK. The effect of parenterally administered cyclodextrins on cholesterol levels in the rat. Pharm Res. 1991;8(1):9-16.

27. Shu HJ, Zeng CM, Wang C, Covey DF, Zorumski CF, Mennerick S. Cyclodextrins sequester neuroactive steroids and differentiate mechanisms that rate limit steroid actions. Br J Pharmacol. 2007;150(2):164-75. https://doi.org/10.1038/sj. bjp.0706973.

28. McGrath M, Raines DE. Anesthetic drug discovery and development: a case study of novel etomidate analogs. Methods Enzymol. 2018;603:153-69. https://doi.org/10.1016/bs.mie.2018.01.026

29. Cotten JF, Husain SS, Forman SA, Miller KW, Kelly EW, Nguyen HH, Raines DE. Methoxycarbonyl-etomidate: a novel rapidly metabolized and ultrashort-acting etomidate analogue that does not produce prolonged adrenocortical suppression. Anesthesiology. 2009;111(2):240-9. https:// doi.org/10.1097/ALN.0b013e3181ae63d1.

30. Ge R, Pejo E, Cotten JF, Raines DE. Adrenocortical suppression and recovery after continuous hypnotic infusion: etomidate versus its soft analogue cyclopropyl-methoxycarbonyl metomidate. Crit Care. 2013;17(1):R20. https:// doi.org/10.1186/cc12494.

31. Roumen L, Sanders MP, Pieterse K, Hilbers PA, Plate R, Custers E, de Gooyer M, Smits JF, Beugels I, Emmen J, et al. Construction of 3D models of the CYP11B family as a tool to predict ligand binding characteristics. J Comput Aided Mol Des. 2007;21 (8):455-71. https:/doi.org/10.1007/s10822-007-9128-9.

32. McCance DR, Hadden DR, Kennedy L, Sheridan B, Atkinson AB. Clinical experience with ketoconazole as a therapy for patients with Cushing's syndrome. Clin Endocrinol. 1987;27(5):593-9 Retrieved from https:// onlinelibrary.wiley.com/journal/13652265.

33. Sonino N, Boscaro M, Paoletta A, Mantero F, Ziliotto D. Ketoconazole treatment in Cushing's syndrome: experience in 34 patients. Clin Endocrinol. 1991;35(4):347-52 Retrieved from https://onlinelibrary.wiley.com/ journal/13652265.

34. Feelders RA, Hofland LJ, de Herder WW. Medical treatment of Cushing's syndrome: adrenal-blocking drugs and ketaconazole. Neuroendocrinology. 2010;92(Suppl 1):111-5. https://doi.org/10.1159/000314292.

35. Nieman LK. Medical therapy of Cushing's disease. Pituitary. 2002:5(2):77-82 Retrieved from https://link.springer.com/journal/11102.
36. Tritos NA, Biller BM, Swearingen B. Management of Cushing disease. Nat Rev Endocrinol. 2011;7(5):279-89. https://doi.org/10.1038/nrendo.2011.12.

37. Verhelst JA, Trainer PJ, Howlett TA, Perry L, Rees LH, Grossman AB, Wass JA, Besser GM. Short and long-term responses to metyrapone in the medical management of 91 patients with Cushing's syndrome. Clin Endocrinol. 1991;35(2):169-78 Retrieved from https://onlinelibrary.wiley.com/ journal/13652265.

38. Pejo E, Santer P, Wang L, Dershwitz P, Husain SS, Raines DE. Gammaaminobutyric acid type a receptor modulation by etomidate analogs. Anesthesiology. 2015. https://doi.org/10.1097/ALN.0000000000000992.

39. Jurd R, Arras M, Lambert S, Drexler B, Siegwart R, Crestani F, Zaugg M, Vogt KE, Ledermann B, Antkowiak B, et al. General anesthetic actions in vivo strongly attenuated by a point mutation in the GABA(a) receptor beta3 subunit. FASEB J. 2003;17(2):250-2. https://doi.org/10.1096/fj.02-0611fje.

40. Cotten JF, Forman SA, Laha JK, Cuny GD, Husain SS, Miller KW, Nguyen HH, Kelly EW, Stewart D, Liu A, et al. Carboetomidate: a pyrrole analog of etomidate designed not to suppress adrenocortical function. Anesthesiology. 2010;112(3):637-44. https://doi.org/10.1097/ALN.0b013e3181cf40ed.

41. Shanmugasundararaj S, Zhou X, Neunzig J, Bernhardt R, Cotten JF, Ge R, Miller KW, Raines DE. Carboetomidate: an analog of etomidate that interacts weakly with 11 beta-hydroxylase. Anesth Analg. 2013;116(6):1249-56. https:// doi.org/10.1213/ANE.0b013e31828b3637.

\section{Publisher's Note}

Springer Nature remains neutral with regard to jurisdictional claims in published maps and institutional affiliations.
Ready to submit your research? Choose BMC and benefit from:

- fast, convenient online submission

- thorough peer review by experienced researchers in your field

- rapid publication on acceptance

- support for research data, including large and complex data types

- gold Open Access which fosters wider collaboration and increased citations

- maximum visibility for your research: over $100 \mathrm{M}$ website views per year

At $\mathrm{BMC}$, research is always in progress.

Learn more biomedcentral.com/submissions 